\title{
Oxidative stress on ischemia/reperfusion injury in mice with non-alcoholic hepatic steatosis or steatohepatitis ${ }^{1}$
}

Natalie Chaves Cayuela', Gabrielly Pascoa Negreti", Roberto Rasslan"', Marcia Kiyomi Koike'v, Edna Frasson de Souza Monterov

'Fellow PhD degree, Postgraduate Program in Surgical Clinics, Laboratory of Surgical Physiopathology - LIM-62, Department of Surgery, Faculdade de Medicina, Universidade de São Paulo (FMUSP), Brazil. Technical procedures, analysis and interpretation of data, statistics analysis, manuscript writing.

"Graduate student, FMUSP, Sao Paulo-SP, Brazil. Technical procedures.

I"PhD, Division of General Surgery and Trauma, LIM-62, Department of Surgery, FMUSP, Sao Paulo-SP, Brazil. Critical revision.

IVPhD, Laboratory of Emergency Medicine - LIM-51, Department of Surgery, FMUSP, Sao Paulo-SP, Brazil. Histopathological examinations.

'PhD, Associate Professor, Laboratory of Surgical Physiopathology - LIM-62, Department of Surgery, FMUSP, Sao PauloSP, Brazil. Conception and design of the study, manuscript writing, final approval.

\section{Abstract}

Purpose: To evaluate the oxidative stress, resulting from ischemia and hepatic reperfusion, in mice with non-alcoholic hepatic steatosis and steatohepatitis.

Methods: C57BL/6 male mice were used. Part of them were ob/ob mice, and the other part was fed with standard or MCD diets - this last used to develop steatohepatitis. The animals - MCD-I/R, ob/ob-I/R and I/R groups - were submitted to 30 minutes of partial hepatic ischemia, followed by reperfusion for 24 hours. The blood was collected, for biochemical analysis of AST, and the liver removed for assessment of TBARS and nitrite, and of histology. Results: After the I/R, the animal fed with MCD diet presented higher AST levels (MCDI/R: $967 \pm 349 \mathrm{U} / \mathrm{L} / \mathrm{ob} / \mathrm{ob}-\mathrm{I} / \mathrm{R}:$ 606 $\pm 18 \mathrm{U} / \mathrm{L} / \mathrm{I} / \mathrm{R}: 311 \pm 172 \mathrm{U} / \mathrm{L}$ ), TBARS (MCD-I/R: $7 \pm 1 \mathrm{nM}$ / mg protein / ob/ob-I/R: $3 \pm 1 \mathrm{nM} / \mathrm{mg}$ protein / I/R: $3 \pm 1 \mathrm{nM} / \mathrm{mg}$ protein) and nitrite (MCDI/R: $614 \pm 87 \mu \mathrm{g} / \mathrm{mL} / \mathrm{ob} / \mathrm{ob}-\mathrm{I} / \mathrm{R}: 512 \pm 81 \mu \mathrm{g} / \mathrm{mL} / \mathrm{I} / \mathrm{R}: 459 \pm 29 \mu \mathrm{g} / \mathrm{mL}$ ) than the ob/ob mice, when both groups were compared to animals fed with standard diet. Regarding histology, the steatosis level (azonal macrovesicular steatosis of level $3->66 \%$ ) and hepatic fibrosis (periportal and perisinusoidal of level 2) was also more intense, but both animal models presented lobular inflammation of level 3 (>66\%).

Conclusions: The murine model fed with MCD diet is suitable for the assessment of oxidative stress in hepatic I/R injury associated with the nonalcoholic fatty liver disease. Although both murine models showed inflammatory infiltrate and macro and micro vesicular steatosis.

Key words: Liver. Fatty Liver. Ischemia. Reperfusion. Oxidative Stress. Models, Animal. Mice. 


\section{- Introduction}

Steatosis is one of the most common forms of hepatic disease $\mathrm{e}^{1,2}$ and is broadly associated to a bad prognosis after surgery in liver $^{3}$, due to the increasing probability of developing primary dysfunction after transplant when compared with non-steatosis livers ${ }^{4,5}$.

The liver with steatosis is not very tolerant to ischemic injury and reperfusion, what may result in hepatic failure and death ${ }^{3,6}$. For example, in orthotopic transplants, moderate and severe steatosis in donated liver is related to the increase in the number of patients with graft dysfunction ${ }^{3}$. It is believed that the causes of vulnerability in liver with steatosis and submitted to ischemia and reperfusion are associated to injuries caused by oxidative stress ${ }^{4}$.

The intracellular accumulation of free fatty acids leads to the development of an inflammatory process and mitochondrial dysfunction by formatting Reactive Oxygen Species (ROS), which impairs cell function and, consequently, results in cell death ${ }^{7-9}$. The reoxygenation during the reperfusion leads to oxidative burst followed by increase in ROS production, which are released by activated Kupffer cells, neutrophils, and $\mathrm{T} \mathrm{CD}^{+}$cells; therefore, causing destruction of hepatic tissue $^{10}$.

To assess the effects of ROS production on the liver with steatosis, different experimental models are used to allow a better comprehension of this disease. In studies referring to Nonalcoholic Fatty Liver Disease (NAFLD), genetically modified mice are frequently used to develop obesity $(o b / o b)$, and in the analysis of Nonalcoholic Steatohepatitis (NASH) its induction is achieved by the use of a specific diet ${ }^{11}$.

The genetically obese animals, such as $o b / o b$ mice, present natural occurrence of a mutation of a spontaneous point in Leptin gene $\left(\right.$ Lep $\left.^{\mathrm{ob}}, o b / o b\right)$, leading to absolute deficiency of this hormone derived from adipocytes, which results in hyperphagia and obesity followed by a syndrome that is similar to type 2 diabetes, where the intolerance to glucose and hyperglycemia ${ }^{12,13}$ is observed. In addition, these mice present elevated levels of insulin and amylin, associated to insulin resistance. The ob/ob mice develop hepatic steatosis, which may worsen with age, from a syndrome similar to NAFLD up to NASH, presenting inflammation and fibrosis. The deficiency of adiponectin hormone is the main reason for the development of steatosis in these animals ${ }^{12}$.

Another model commonly used in the development study of NASH in mice is the administration of a methionine cholinedeficient (MCD) diet for rodents ${ }^{11,14}$. The animals submitted to MCD diet loose around $25 \%$ of their weight in two weeks and reduce size $^{11}$. In addition, develop inflammation mainly with lymphocytes and neutrophils - severe steatosis, steatohepatitis, and fibrosis. The oxidative stress, present in this model, is considered an important factor for the progression of steatosis condition to steatohepatitis ${ }^{11}$.

Considering the specificities of each model in the ischemia lesion and hepatic reperfusion, the purpose of this work was to comparatively assess the effect of oxidative stress after the ischemia and reperfusion in $o b / o b$ mice and in animals submitted to MCD diet.

\section{- Methods}

The study was developed after the approval by the Ethics Committee of Faculdade de Medicina da Universidade de 
São Paulo - FMUSP (Process number 243/13). All animals were handled according to the "Ethical Principles of Animal Experimentation of International Union of Animal Protection" and Brazilian Law No. 11.794, from October 8, 2008.

Animals were housed in appropriate cage of dimensions $40 \times 30 \times 25 \mathrm{~cm}$ in groups of three animals, and it was kept with specific chow according to the group and water ad libitum. The circadian rhythm of the animals was respected maintaining the adequate sanitary conditions. Before the experiments, the animals had a solid food restriction of four hours.

It was used twenty-four male mice, eight weeks old, C57BL/6 and genetically modified obese $(o b / o b)$, both strains were purchased from Central Animal Facilities of the Medical School - University of São Paulo. (São Paulo, Brasil). The animals were distributed in the following experimental groups ( $N=6$ each group): Control = mice $\mathrm{C} 57 \mathrm{BL} / 6$ fed with standard diet; $\mathrm{I} / \mathrm{R}=\mathrm{C} 57 \mathrm{BL} / 6$ mice fed with standard diet and submitted to ischemia and reperfusion; $M C D-I / R=C 57 B L / 6$ mice fed with methionine-choline deficient diet (MCD diet - purchase from Rhoster Ind. Com. LTDA Araçoiaba da Serra - SP- Brasil) and submitted to ischemia and reperfusion; $o b / o b-\mathrm{I} / \mathrm{R}=$ mice genetically modified to develop steatosis fed with standard diet and submitted to ischemia and reperfusion. The standard and MCD diets were administrated to the proper groups for a one-month period.

\section{Surgical procedure}

The animals were sedated with an association of xylazine $(10 \mathrm{mg} / \mathrm{Kg})$ and ketamine $(70 \mathrm{mg} / \mathrm{kg})$ drugs, via intramuscular, and submitted to ischemia during 30 minutes by clamping of portal triad for left and middle liver lobes, afterwards removed removing the clamps and allowing the reperfusion for 24 hours. The abdominal wall of the mice was sutured with polypropylene thread 7-0, and they were maintained in cages with water and ad libitum food. The animals were sedated again, after the reperfusion, and re-operated to collect blood and to surgically remove lateral left and median lobes, which were divided in three fragments: one for histology, fixed in formalin $10 \%$, and two for nitrite dosage and MDA, which were frozen in liquid nitrogen and maintained in freezer $-80^{\circ} \mathrm{C}$. Euthanasia was performed through exsanguination, while mice were still sedated.

\section{Histologic and biochemical analysis}

The liver fragment fixed in formalin $10 \%$ was embedded in paraffin. Afterwards, histologic cuts were made $4 \mu \mathrm{m}$ thick, colored by $\mathrm{H} / \mathrm{E}$ method. The tissue cuts were assessed according to histological parameters of Kleiner et $a l .{ }^{15}$ by an examiner using a blinding technique for the groups.

The blood of the animals was centrifuged at $3500 \mathrm{~g}$ for 15 minutes, and the serum was collected and stored in freezer at $-80^{\circ} \mathrm{C}$ for further analysis of aspartate aminotransferase (AST). This analysis was realized by the Biochemistry Laboratory of the FMUSP.

\section{Detection of lipid peroxidation}

For the analysis of malondialdehyde (MDA) in liver, the fragments were then unfrozen, diluted at $100 \mathrm{mg} / \mathrm{mL}$ in phosphate buffer ( $\mathrm{pH}$ 7.2), homogenized, centrifuged at $10,000 \mathrm{~g}$ for 15 minutes, and the supernatant collected. Initially, the amount of total proteins was verified in the liver. The hepatic tissue was diluted in a proportion of 1:5 in distilled 
water, and $20 \mu \mathrm{L}$ of this solution was added to $1 \mathrm{~mL}$ of Bradford Reagent. The absorbance was read in spectrophotometer Model TPReader (ThermoPlate-China), with $595 \mathrm{~nm}$ wave length. Afterwards, the samples were diluted in the same proportion used for the quantification of total proteins and mixed to $250 \mu \mathrm{L}$ of Trichloroacetic acid (TCA) at $17.5 \%$ and $250 \mu \mathrm{L}$ of Thiobarbituric acid (TBA) at $0.6 \%$ $(\mathrm{pH} 2.0)$. The samples were placed in waterbath for 15 minutes at $95^{\circ} \mathrm{C}$, cooled in ice for 15 minutes, and $250 \mu \mathrm{L}$ of TCA at $70 \%$ was then added, and then incubated for 20 minutes at $4^{\circ} \mathrm{C}$ and centrifuged at $1609 \mathrm{~g}$ for 15 minutes. The absorbance was read in spectrophotometer Model TP-Reader (ThermoPlate - China), with $534 \mathrm{~nm}$ wave length. The MDA concentration was provided in $\mathrm{nmol}$ of MDA per $\mathrm{mg}$ of protein.

\section{Nitrite quantification}

The nitrite, byproduct of the nitric oxide (NO) degradation, was quantified in the liver parenchyma using Griess reagent technique. Liver fragments were unfrozen, diluted at $100 \mathrm{mg} / \mathrm{mL}$ in phosphate buffer $(\mathrm{pH}$ 7.2), homogenized, centrifuged at $10,000 \mathrm{~g}$ for 15 minutes, and the supernatants collected. In a plate with 96 wells, $50 \mu \mathrm{L}$ of each sample and from standard curve dilutions with $50 \mu \mathrm{L}$ of Griess reagent, previously prepared with volumes equal to the component $\mathrm{A}$ ( $\mathrm{N}$-(1naphthyl) ethylenediaminedihydrochloride) and the component $B$ (sulphanilic acid) was mixed. The photometric reference sample was prepared mixing $50 \mu \mathrm{L}$ of Griess Reagent and $50 \mu \mathrm{L}$ of deionized water. The absorbance of samples was measured in spectrophotometer
Model TP-Reader (ThermoPlate - China), with $548 \mathrm{~nm}$ wave length.

\section{Statistical analysis}

The values of AST, TBARS and nitrite were presented in Mean \pm Standard Deviation. For statistical analysis of results purposes, the test ANOVA one way and the post-test of Bonferroni, using the level of significance in $5 \%$ $(p<0.05)$ was applied.

\section{- Results}

\section{Histopathologic and biochemical analysis}

From the histopathologic analysis, it was possible to observe that the liver of animals from the control group maintained the normal architecture (Figure 1A), while the animals submitted the ischemia and reperfusion (group $\mathrm{I} / \mathrm{R})$ present steatosis micro vesicular level 2 $(<33 \%)$, without the presence of inflammatory infiltrate (Figure 1B).

After the ischemia and reperfusion procedure, the animals fed with DMC diet present a more severe injury than the ones found in $o b / o b$ mice, in respect to the steatosis level in hepatic tissue, being observed the predominance of steatosis macro vesicular azonal level 3 (<66\%) (Figure $1 \mathrm{C}$ ) and level 2 periportal and perisinusoidal hepatic fibroses areas. In $o b / o b$ animals, in turn, was found macro steatosis and micro vesicular level 2 (<33\%) (Figure 1D) and level 1 periportal hepatic fibrosis. Regarding inflammation, both animal models presented level 3 lobular inflammation (Figure 1 C-D). 


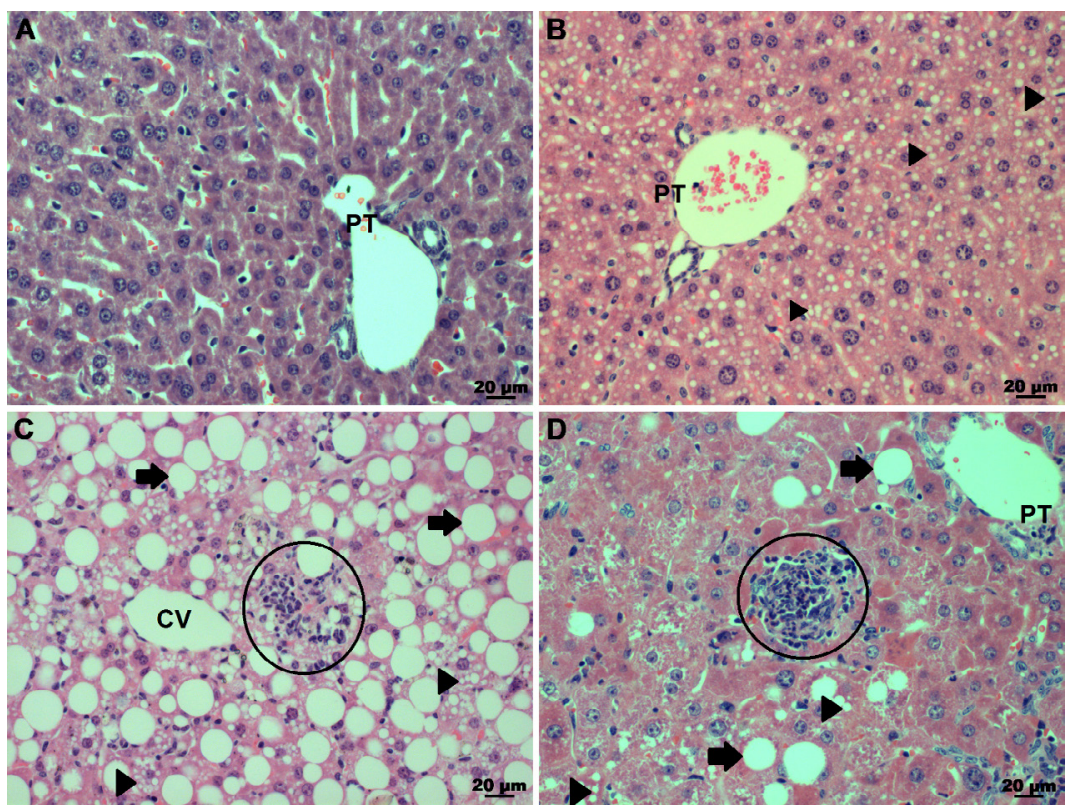

Figure 1 - Photomicrographs of hepatic tissue sections stained with $\mathrm{H} / \mathrm{E}$ of (A) mice from control group, presenting normal architecture, of (B) mice from I/R group, presenting micro vesicular steatosis (arrow heads), of (C) mice from MCD-I/R group, which presented inflammatory infiltrate (circled area) and predominance of macro vesicular steatosis (arrows), and (D) mice from ob/ob-l/R group, in which macro vesicular steatosis (arrows) and micro vesicular (arrow heads) and presence of inflammatory infiltrate (circled area) are observed. Images represented with $\times 40$ magnification. $\mathrm{PT}=$ portal tract; $\mathrm{CV}=$ central vein.

Regarding the serological analysis (Figure 2A), after the $1 / R$, the mice fed with DMC diet presented higher levels of AST $(967$ $\pm 349 \mathrm{U} / \mathrm{L}$ ) than the ob/ob animals (606 \pm 18
$\mathrm{U} / \mathrm{L})$, when compared to the animals fed with standard diet and submitted to I/R (311 \pm 172 U/L) was observed.
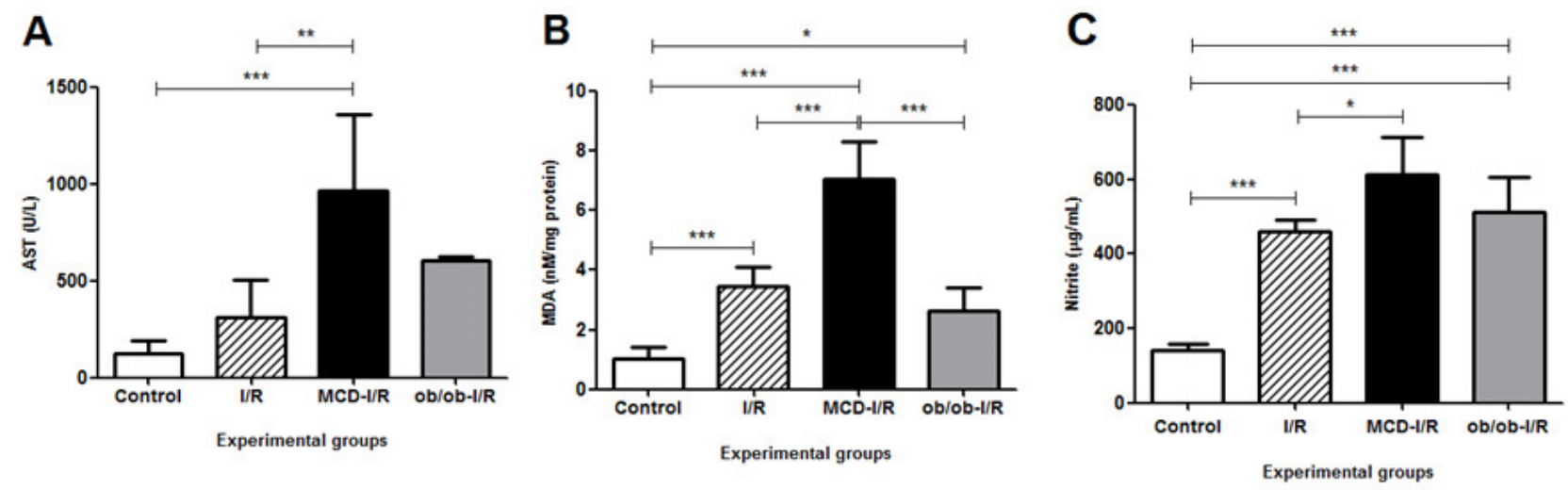

Figure 2 - Assessment of hepatic injury. (A) AST Levels, (B) of TBARS and (C) of nitrite in liver of mice fed with standard diet (Control group), submitted to I/R (group I/R), fed with MCD diet associated to I/R (MCD-I/R), and ob/ob mice submitted to $\mathrm{I} / \mathrm{R}$ (ob/ob). The asterisks represent the statistical significance of results, where ${ }^{*}=p<0.05 ; * *=p<0.01$ and ${ }^{* * *}=p<0.001$. 


\section{Evaluation of lipid peroxidation and nitrite}

Additionally, the evaluation of oxidative stress in hepatic tissue (Figure 2B and 2C) showed an increase in TBARS and nitrite levels, after the $I / R$, was greater in the animals fed with MCD diet (TBARS: $7 \pm 1 \mathrm{nM} / \mathrm{mg}$ protein / nitrite: $614 \pm 87 \mu \mathrm{g} / \mathrm{mL}$ ) than in ob/ob animals (TBARS: $3 \pm 1 \mathrm{nM} / \mathrm{mg}$ protein / nitrite: $512 \pm 81$ $\mu \mathrm{g} / \mathrm{mL}$ ), when compared to the animals fed with conventional diet and submitted to $1 / R$ (TBARS: $3 \pm 1 \mathrm{nM} / \mathrm{mg}$ protein / nitrite: $459 \pm 29$ $\mu \mathrm{g} / \mathrm{mL})$.

\section{- Discussion}

In this study, the animals from experimental models of hepatic steatosis and steatohepatitis assessed were submitted to ischemia for 30 minutes followed by reperfusion for 24 hours, with the purpose of observing the effects of I/R procedure over the oxidative stress in hepatic tissue with steatosis. After the I/R procedure, the increase of oxidative stress in mice that developed steatohepatitis due to the ingestion of MCD diet was more intense when compared to that occurred in ob/ob mice, which developed only hepatic steatosis. However, the presence of inflammatory infiltrate was observed in both models of animals evaluated, not occurring difference with respect to this histologic parameter.

The $I / R$ injury is one of the main clinical problems that appear during the hepatic transplant and partial liver resection surgery, being one of the most common causes of hepatic dysfunction, graft rejection and chronic diseases ${ }^{16}$. When the I/R injury is associated with hepatic steatosis, the effects of the inflammatory process is exacerbated, causing an even more intense injury to the liver ${ }^{17-19}$, which results in poor prognosis in hepatobiliary surgeries, hepatectomies and liver transplantation ${ }^{20}$.
In our study, both animal models of hepatic injury, ob/ob mice and those fed with MCD, showed infiltrate of inflammatory cells in liver submitted to $I / R$, which may have led to an injury in hepatic tissue, evidenced by the presence of fibrosis.

According to Takahashi et al. ${ }^{21}$, the young ob/ob mice only show hepatic inflammation after manipulation of the diet or exposure to toxins; but, Sutter et al. ${ }^{22}$ affirms that these mice with approximately 20 weeks of age may present a significant increase of inflammatory activity, with the presence of inflammatory mediators and neutrophils, even when fed with normal diet. Like in ob/ $o b$ mice, the animals of C57BL/ 6 strain, when fed with MCD diet, also present increase of inflammatory response ${ }^{23}$. The studies of Sutter et $a .^{22}$ and Yu et al. ${ }^{23}$ corroborate with our results, in which was observed the presence of inflammatory infiltrate in steatosis hepatic tissue of both animal models.

The Kupffer cells and CD4+ lymphocytes, when activated by $\mathrm{l} / \mathrm{R}$, are the main producers of inflammatory mediators in liver cells, with cytokines and chemokines ${ }^{24}$. Such mediators promote the recruitment of neutrophils, which are responsible for the induction of oxidative stress in liver post-ischemic ${ }^{25,26}$. The oxidative stress occurs due to the unbalance between ROS and the detoxification capacity of tissue through antioxidant enzymes, causing therefore tissue destruction ${ }^{27,28}$. In physiological conditions, the synthesis of ROS is balanced with the number of antioxidants present in the organs; however, if the ROS concentration exceeds the normal values and the antioxidants are unable to compensate the excess, these free radicals end up causing lipid damage, proteins, and DNA ${ }^{29}$.

Regarding oxidative stress in liver, the production of TBARS and nitrite after the I/R procedure presented significantly elevated levels only in mice fed with MCD diet. These 
develop a steatohepatitis, when compared to $o b / o b$ mice fed with standard diet, which presented only hepatic steatosis. This could be the cause of the difference in production of ROS between the models.

The steatosis causes liver inflammation with ROS production and, as consequence, the hepatocytes develop vulnerability to oxidative stress, which in turn, is the main responsible for progression of NAFLD for a steatosis associated to necroinflammation and fibrosis, denominated $\mathrm{NASH}^{30}$. It is believed that hepatic steatosis causes the obstruction of hepatic microcirculation and mitochondrial dysfunction, which results in the increase of ROS production as subsequent cell death ${ }^{30}$. In addition, according to Gehrau et al. ${ }^{19}$, the lipid peroxidation is also associated to hepatic steatosis and represent an additional source for ROS production, contributing to intensify $I / R$ injury. Our results corroborate with these studies, once the fatty infiltration in liver was severe in animals fed with MCD diet causing the increase in TBARS levels and in nitrite. These, in turn, may have promoted the evolution for NASH in these animals, since steatosis in hepatic tissue and oxidative stress are intimately related.

\section{Conclusions}

The murine model fed with methionine choline-deficient diet is suitable for the assessment of oxidative stress in hepatic I/R injury associated with the nonalcoholic fatty liver disease. Although both murine models showed inflammatory infiltrate and steatosis macro vesicular and micro vesicular.

\section{References}

1. Basaranoglu $M$, Kayacetin $S$, Yilmaz $N$, Kavacetin E, Tarcin O, Sonsuz A. Understanding mechanisms of the pathogenesis of nonalcoholic fatty liver disease. World J Gastroenterol. 2010 May 14;16(18):2223-6. doi: 10.3748/wjg.v16. i18.2223.

2. Sanches SCL, Ramalho LNZ, Augusto MJ, Silvia DMS, Ramalho FS. Nonalcoholic steatohepatitis: a search for factual animal models. Biomed Res Int. 2015; 2015:574832. doi: $10.1155 / 2015 / 574832$.

3. Chu MJ, Hickey AJR, Phillips ARJ, Bartlett AJR. The impact of hepatic steatosis on hepatic ischemia-reperfusion injury in experimental studies: a systematic review. Biomed Res Int. 2013;;2013:192029. doi: 10.1155/2013/192029.

4. Ahmed EA, ElBadry AM, Hassan AEA, Redwan AA, Vivarelli $M$. Review on liver steatosis and its impact on liver transplantation. J Liv Res Dis Ther. 2017 Sep 21;3(4):00064. doi: 10.15406/jlrdt.2017.03.00064.

5. Nativ NI, Maguire TJ, Yarmush G, Brasaemle DL, Henry SD, Guarrera JV, Berthiaume F, Yarmush ML. Liver defatting: an alternative approach to enable steatotic liver transplantation. Am J Transplant. 2012 Dec;12(12):3176-83. doi: 10.1111/j.16006143.2012.04288.x.

6. de Graaf EL, Kench J, Dilworth P, Shackel NA, Strasser SI, Joseph D, Pleass H, Crawford M, McCaughan GM, Verran DJ. Grade of deceased donor liver macrovesicular steatosis impacts graft and recipient outcomes more than the donor risk index. J Gastroenterol Hepatol. 2012 Mar;27(3):5406. doi: 10.1111/j.1440-1746.2011.60844.x.

7. Evans ZP, Ellett JD, Fariss MW, Schenellmann RG, Schmidt MG, Chavin K. Vitamin E succinate reduces ischemia/reperfusion injury in steatotic livers. Transplant Proc. 2008 Dec;40(10):3327-9. doi: 10.1016/j. transproceed.2008.06.076.

8. Gomez-Quiroz LE, Factor VM, Kaposi-Novak $P$, Coulouarn C, Conner EA, Thorgeirsson SS. Hepatocyte specific c-Met deletion disrupts redox homeostasis and sensitizes to Fas-mediated apoptosis. J Biol Chem. 2008;283:14581-9. doi: 10.1074/jbc. M707733200.

9. Trauner $M$, Arrese $M$, Wagner M. Fatty liver and lipotoxicity. Biochim Biophys Acta. 2010 Mar;1801(3):299-310. doi: 10.1016/j. bbalip.2009.10.007.

10.Lee AJ, Kang JH, lqbal W, Kwon O-S. Proteomic analysis of mice fed methionine 
and choline deficiente diet reveals marker proteins associated with steatohepatitis. Plos One. 2015 Apr 7;10(4):e010577. doi: 10.1371/journal.pone.0120577.

11.Marcolin E, Fotgiarini LF, Tieppo J, Dias AS, Freitas LA, Marroni NP. Methionineand choline-deficient diet induces hepatic changes characteristic of non-alcoholic steatohepatitis. Arg Gastroenterol. 2011 Jan-Mar;48(1):72-9. PMID: 21537547.

12. Church SJ, Begley P, Kureishy N, McHarg S, Bishop PN, Bechtold DA, Unwin RD, Cooper GJ. Deficient copper concentrations in drieddefatted hepatic tissue from ob/ob mice: A potencial model for study of defective copper regulation in metabolic liver disease. Biochem Biophys Res Commun. 2015 May 8;460(3):549-54. doi: 10.1016/j. bbrc.2015.03.067.

13. Ohyama T, Sato K, Yamazaki Y, Hashizume $\mathrm{H}$, Horiguchi N, Kakizaki S, Mori M, Kusano M, Yamada M. MK-0626, a selective DPP-4 inhibitor, attenuates hepatic steatosis in ob/ ob mice. World J Gastroenterol. 2014 Nov 21;20(43):16227-35. doi: 10.3748/wjg.v20. i43.16227.

14. Rinella ME, Green RM. The methioninecholine deficient dietary model of steatohepatites does not exhibit insulin resistance. J Hepatol. 2004 Jan;40(1):47-51. PMID:14672613.

15.Kleiner DE, Brunt EM, Van NM, Behling C, Contos MJ, Cummings OW, Ferrel LD, Liu YC, Torbenson MS, Unalp-Arida A, Yeh M, McCullough AJ, Sanyal AJ. Design and validation of a histological scoring system for nonalcoholic fatty liver disease. Hepatology. 2005;41(6):1313-21. doi: 10.1002/hep.20701.

16.El-Shitany NA, El-Desoky K. Cromoglycate, not ketotifen, ameliorated the injured effect of warm ischemia/reperfusion in rat liver: role of mast cell degranulation, oxidative stress, proinflammatory cytokines, and inducible nitric oxide synthase. Drug Des Devel Ther. 2015 Sep 16;9:5237-46. doi: 10.2147/DDDT.S88337.

17. He S, Atkinson C, Evans Z, Ellet JD, Southwood $M$, Elvington $A$, Chavin KD, Tomlinson S. A role for complement in the enhanced susceptibility of steatotic livers to ischemia and reperfusion injury. J Immunol. 2009 Oct 1;183(7):4764-72. doi: 10.4049/ jimmunol.0900550.

18. Eltzschig HK, Eckel T. Ischemia and reperfusion - from mechanism to translation. Nat Med. 2011 Nov 7;17(11):1391-401. doi: 10.1038/nm.2507.

19.Gehrau RC, Mas VR, Dumur Cl, Suh JL, Sharma AK, Cathro HP, Maluf DG. Donor hepatic steatosis induce exacerbated ischemia-reperfusion injury through activation of innate immune response molecular pathways. Transplantation. 2015 Dec;99(12):2523-33. doi: 10.1097/ TP.0000000000000857.

20. Matheson PJ, Hurt RT, Franklin GA, McClain CJ, Garrison RN. Obesity-induced hepatic hypoperfusion primes for hepatic dysfunction after resuscitation hemorrhagic shock. Surgery. 2009 Oct;146(4):739-47. doi: 10.1016/j.surg.2009.06.037.

21.Takahashi Y, Soejima Y, Fukusato T. Animal models of nonalcoholic fatty liver disease/ nonalcoholic steatohepatitis. World J Gastroenterol. 2012 May 21;18(19):2300-8. doi: 10.3748/wjg.v18.i19.2300.

22.Sutter AG, Palanisamy AP, Lech JH, Jessmore Ap, Clavin KD. Development of steatohepatitis in ob/ob mice is dependente on toll-like receptor-4. Ann Hepatol. 2015 Sep-Oct;14(5):735-43. PMID: 26256903.

23.Yu J, Ip E, Dela Peña A, Hou JY, Sesha J, Pera N, Kirsch R, Leclercg I, Farrell GC. COX-2 induction in mice with experimental nutritional steatohepatitis: role as proinflammatory mediator. Hepatology. 2006 Apr;43(4):826-36. doi: 10.1002/hep.21108.

24.Caldwell CC, Okaya T, Martignoni A, Husted $T$, Schuster $R$, Lentsch $A B$. Divergent functions of $C D 4+T$ lymphocytes in acute liver inflammation and injury after ischemiareperfusion. Am J Physiol Gastrointest Liver Physiol. 2005;289(5):G969-76. doi: 10.1152/ ajpgi.00223.2005.

25. Harada H, Hines IN, Flores S, Gao B, McCord J, Scheerens H, Grisham MB. Role of NADPH oxidase-derived superoxide in reduced size liver ischemia and reperfusion injury. Arch Biochem Biophys. 2004;423:103-8. doi: 10.1016/j.abb.2003.08.035.

26. Hasegawa T, Ito Y, Wijeweera J, Liu J, Malle E, Farhood A, McCuskey RS, Jaeschke $H$. Reduced inflammatory response and increased microcirculatory disturbances during hepatic ischemia-reperfusion 
injury in steatotic livers of $o b / o b$ mice. Am J Physiol Gastrointest Liver Physiol. 2007 May;292(5):G1385-95. doi: 10.1152/ ajpgi.00246.2006.

27.Delbosc S, Paizanis $E$, Magous $R$, Araiz C, Dimo T, Cristol JP, Cros G, Azay J. Involvement of oxidative stress and NADPH oxidase activation in the development of cardiovascular complications in a model of insulin resistance, the fructose-fed rat. Atherosclerosis. 2005;179(1):43-9. doi: 10.1016.j.atherosclerosis.2004.10.018.

28.Tugrul S, Kocyigit A, Dogan R, Eren S, Senturk E, Ozturan O, Ozar OF. Total antioxidant status and oxidative stress in recurrent aphthous stomatitis. Int J Dermatol. 2016 Mar;55(3):e130-5. doi: 10.1111/ijd.13101.

29.Chang CC, Jou SH, Lin TT, Liu CS. Mitochondria DNA variation and increased oxidative damage in euthymic patients with bipolar disorder. Psychiatry Clin Neurosci. 2014;68:551-7. doi: 10.1111/pcn.12163.

30. Rolo AP, Teodoro JS, Palmeira CM. Role of oxidative stress in the pathogenesis of nonalcoholic steatohepatitis. Free Rad Biol Med. 2012;52(1):59-69. doi: 10.1016/j. freeradbiomed.2011.10.003.

\section{Acknowledgements}

To Prof. Dr. Edivaldo Massazo Utiyama for the support in the development of this project, and the technicians Luci Yukiko Takasaka, Elisabete Hiroe Minami, Marco de Luna, and Mario Matsuo Itinoshe from the LIM-62, who helped with the experiments.

\section{Correspondence:}

Edna Frasson de Souza Montero

Alameda Espada, 134

06540-395 Santana de Parnaíba - SP Brasil

edna.montero@fm.usp.br

Received: May 14, 2018

Review: July 10, 2018

Accepted: Aug 13, 2018
Conflict of interest: none

Financial source: CAPES

${ }^{1}$ Research performed at Laboratory of Surgical Physiopathology (LIM-62), Department of Surgery, Faculdade de Medicina, Universidade de São Paulo (FMUSP), Brazil. Part of PhD degree thesis, Postgraduate Program in Surgical Clinics. Tutor: Prof. Edna Frasson de Souza Montero. 